Relationship between Work-Family Conflict, Organizational Commitment and Welfare in The Workplace among Working Women

Nurul-Azza Abdullah, Nursya Fitrah binti Adenan, Nur Shaffika Izzaty Mohd Zaiedy

To Link this Article: http://dx.doi.org/10.6007/IJARBSS/v11-i3/8925

DOI:10.6007/IJARBSS/v11-i3/8925

Received: 12 January 2021, Revised: 15 February 2021, Accepted: 28 February 2021

Published Online: 13 March 2021

In-Text Citation: (Abdullah et al., 2021)

To Cite this Article: Abdullah, N.-A., Adenan, N. F. binti, \& Zaiedy, N. S. I. M. (2021). Relationship between Work-Family Conflict, Organizational Commitment and Welfare in The Workplace among Working Women. International Journal of Academic Research in Business and Social Sciences, 11(3), 154-168.

Copyright: (c) 2021 The Author(s)

Published by Human Resource Management Academic Research Society (www.hrmars.com)

This article is published under the Creative Commons Attribution (CC BY 4.0) license. Anyone may reproduce, distribute, translate and create derivative works of this article (for both commercial and non-commercial purposes), subject to full attribution to the original publication and authors. The full terms of this license may be seen at: http://creativecommons.org/licences/by/4.0/legalcode

Vol. 11, No. 3, 2021, Pg. 154 - 168

Full Terms \& Conditions of access and use can be found at http://hrmars.com/index.php/pages/detail/publication-ethics 


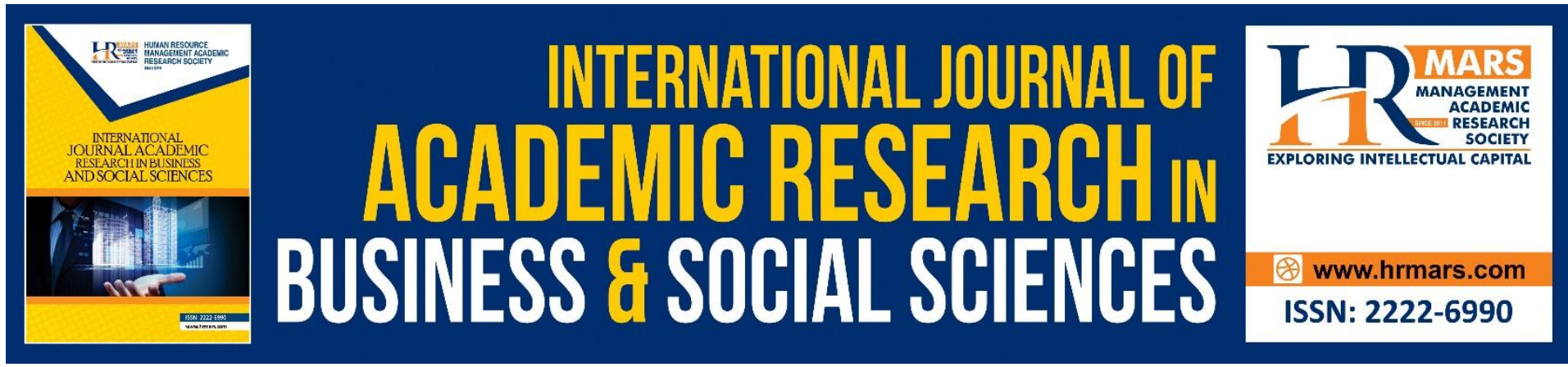

\title{
Relationship between Work-Family Conflict, Organizational Commitment and Welfare in The Workplace among Working Women
}

\author{
Nurul-Azza Abdullah, Nursya Fitrah binti Adenan, Nur Shaffika \\ Izzaty Mohd Zaiedy \\ Psychology and Human Well-Being Research Centre, Faculty of Social Sciences and \\ Humanities, Universiti Kebangsaan Malaysia, Bangi, Selangor.
}

\begin{abstract}
Abstratct
Women's involvement in the professional career sector is increasing today. The increase of women in the workforce has involved them in a variety of tasks which could lead to changes in their family structure and workplace. This situation will create conflict, impact commitment, and even affect the well-being of women in the workplace. Therefore, the objective of this study is to see how conflict, commitment, and well-being are related to working women. This quantitative study applied questionnaire techniques which is a survey method to collect data. This study was conducted in several districts in Selangor using Organizational Commitment Questionnaire (OCQ) by Porter and Smith (1970), Work-Family Conflict Questionnaire by Kelloway, Gottlieb, and Barham (1999) and Well Being at Work Scale by Paschoal and Tamayo (2008). The findings of this study indicate that the existence of a significant impact relationship between work-family conflict and organizational commitment and also identified age and duration variability of marriage is a significant predictor of well-being in the workplace.
\end{abstract}

\section{Introduction}

The empowerment of women's participation in the employment sector is increasing. The government today is doing its best to increase the number of women involved in the national decision-making process. Statistics from the Department of Statistics Malaysia (2018), showed that the participation of women in the employment sector in the fourth quarter of 2017 was 5.60 million and increased by 0.11 million in the first quarter of 2018 which is 5.71 million for women.

The involvement of women who are married with children in the employment sector is not a foreign thing in Malaysia. Working mothers need to divide their time between work, family, and workplace. The increase in women in the employment sector has involved them in diverse tasks in the organization causing changes in the family structure.

In this competitive world, working women are an interesting topic because of their involvement in various professional employment sectors. A study conducted by Abdullah et 
al. (2012) entitled Perceptions of Career Barriers Among Working Women stated that the significant role of women and their contribution to national development should not be disputed. The increase in women in the professional sector has enabled economic change to occur and has seen women as a necessity in the work sector. However, they are always in the dilemma of responsibility for the organization and the family.

Working women have their challenges when it comes to their ability to divide time between work and family. The involvement and role of working women in various aspects such as business, education, politics, and so on have made a significant contribution. Working women who are called wives and mothers are an undeniable source of inspiration.

The traditional way of thinking believes women play a key role in managing household and family and that they do not have to work. But today's situation changes when professions involving women allow them to have identity status in the workplace. The profession owned by working women allows their needs to help and provide financial and economic support to the family.

According to Rangarajan (2018), women's exposure to education and technology enables them to face dual roles as working mothers in terms of personal life and work life. Besides, various aspects such as time management, workload, lack of coordination with colleagues, lack of support from family can also have an impact on working women. Despite the pressures, most of these working women are not easily discouraged and manage to stay in their profession of work. As women with the title of mother, they also want to meet personal expectations in life at work and also at home.

Increasing the number of women in the employment sector at the same time having responsibilities to the family is not uncommon in our country. A study conducted by Ahmad and Ngah (2011) stated that single mothers who experience conflict are not able to continue working well and become less satisfied with their work, the results of the study also showed that increasing work-family conflict will contribute to decreased job satisfaction. Besides, this study also suggested that organizations need to reduce the workload to reduce work-family conflicts that can affect job satisfaction.

The work-family conflict occurs as a result of the imbalance of work and family role demands that are not in line and have had a negative impact on working women. The large and dual role of responsibility has led to an increase in work-family conflict among working women. The stress faced results in the onset of work-family conflicts, especially in the workplace. (Noorazwana \& Agnis, 2017). Reducing work-family conflict enables working mothers to achieve organizational commitment and well-being in the workplace.

According to Meyer and Allen (1984), employees who commit to the organization will better survive as part of the organization and continue to work. Existing organizational commitment allows employees to have meaningful experiences with the organization, and understand organizational goals. However, the existence of an increase in role conflicts among working women makes the commitment of this organization unattainable. 
The rise of women in the employment sector is a global phenomenon and Malaysia is no exception. Diverse roles can have an impact on their well-being in the workplace. The wellbeing achieved can have an impact on employee engagement and productivity. (Bryson, Forth \& Stokes, 2014). Good health enabling these working women to achieve organizational commitment and reduce work-family conflict.

Therefore, this study aims to examine the involvement of working mothers in the employment sector through the existing family-work conflict, organizational commitment, and well-being in the workplace.

\section{Research Problem}

Working women are always faced with conflict and they are not able to give the best attention and commitment in the organization if they have family problems. The ongoing conflict in the role of working women creates various daily functional disorders and can lead to various cases as reported in the time media, for example, cases of mothers forgetting and leaving their babies in the car causing death. This is known as Forgotten Baby Syndrome (FBS). FBS is the incident of a parent accidentally leaving a baby in a hot, locked car. This happens when mothers change their original daily or emotional and mental routines in a state of stress and unable to focus on problems and in turn create work-family conflict and organizational commitment. This problem can be overcome if the conflict can be reduced. A study conducted by Ngah et al. (2010) stated that the reduction of work-family conflict can increase organizational commitment.

In addition, according to the Journal of Psychology and Counseling (2018) stated that society facing various issues involving physical and mental elements will have an impact that affects their level of well-being (Zuriani et al., 2018). Most working women who experience workfamily conflict will give a negative attitude at work which in turn disrupts their well-being at work. However, the extent to which the healthy and prosperous development of an individual depends a lot on internal and external factors. Therefore, this study to see the relationship of well-being in the workplace despite the existence of work-family conflict among working mothers can be achieved.

In turn, well-being in the workplace can influence organizational commitment. Employees who achieve well-being provide opportunities for the organization to stay and reduce employee turnover behavior. This study allows researchers to identify whether well-being in the workplace can positively affect affective and normative commitment and negatively affect continuity commitment.

\section{Literature Review}

\section{Age and Period of Marriage Significant Predictive Factors on Workplace Well-Being.}

Well-being in the workplace has a huge impact on happiness in life and work skills that directly affect one's work productivity. Well-being in the workplace will also result in a good work environment and there is various consensus that says the importance of well-being in the workplace for individuals and to the organization. In addition, employee understanding according to age factors should be taken into account as each phase of the test is specific to prove different well-being rates. In order to retain and attract talent, the organization must 
offer conducive conditions to employees to maintain performance, well-being, and personal achievement.

According to Warr (2007), there are two types of well-being or happiness. The first is cognitive happiness involving positive affective and negative affective. Emotional feelings of pleasure, joy, and comfort are representative of the positive affective component and indicate good well-being. While emotional feelings such as dissatisfaction, anxiety, and depression represent negative effects and low well-being. The second type of happiness refers to selfvalidation and is related to cognitive happiness. Self-affirmation is feelings such as personal contributions, potential exploration, achievement, and self-expression and is accompanied by happy feelings.

In addition, the discussion of well-being in the workplace also involves fulfillment and selfaccomplishment. When people feel a good achievement experience they are more satisfied with life and the prevalence of positive effects will be clear. Happy experiences are also expected to go beyond situations such as the feeling that their needs are sufficient, physical, and social satisfaction as well as the feeling that their life is comfortable and safe. Therefore, the achievement is one of the contributions to explain the variation of well-being in the workplace.

Demographic characteristics such as age and duration of marriage are good predictor factors for well-being in the workplace. The increasing role of employment in line with the factors of age and duration of marriage can be seen to determine good well-being in the workplace. Both of these factors can be considered for a clearer understanding of the phenomena and antecedents that occur.

The study of population age is important because it provides insights into the impact on growth, support of social systems, and the ability of communities to supply good resources to society. Well-being increases with age and older workers enjoy better well-being. According to Boult (2019), increasing age proves an increase in well-being in the workplace. This study also outlines that various aspects indicate the development of employees increases through age factors and employees also evaluate their development through experience. Today's employees also see their progress with every career experience. This means that if they can learn to apply well-being then they can achieve good achievements in life.

The second predictor factor is the period of marriage. According to Boult (2019), among the activities that support workplace well-being is time spent with family. Positive experiences with family and friends are positively correlated with well-being at work because it can reduce negative emotions. A long period of marriage proves that individuals who have a partner experience positive experiences throughout their marriage. Long marriages also mean the existence of good quality of marriage, family functioning, work-life balance, and good familywork integration.

\section{Age as a Predictor of Well-Being in the Workplace}

Age factors such as younger employees or older employees can influence how they work and how they manage their emotions. In addition, job characteristics and job design can also have a different effect on employee well-being (Zacher \& Schmitt, 2016). Therefore, the focus on 
the role of employee age in the relationship between job characteristics and job well-being is given attention. According to Hackman and Oldham (1976), age-related changes in the characteristics of individual differences such as cognitive and physical abilities, personality, and motives are also related to occupational well-being.

Older employees usually have their way of improving well-being. They do not need an organization to create a conducive environment for them because older employees have a way to feel happy and healthy at work compared to younger employees. Boult's (2019) study states that older workers create their ways to support workplace well-being. Among them is through the experience of their achievements at a young age causing them to feel safe while working. Older workers also believe that an effective job is to have good workplace wellbeing.

A significant approach to employees to have opportunities that can attract interest, engage in learning, foster positive emotional experiences and autonomous ability is a challenge for the organization. Thus, help from older employees helping younger employees by providing motivational edits and useful influences for them is one of the good efforts in fostering wellbeing in the workplace (Webber, 2019).

\section{Marriage Period as a Predictor of Well-Being in the Workplace.}

Studies on the duration of marriage and well-being have not yet been expanded but the quality of marriage and marital satisfaction is the yardstick to the duration of the marriage and interrelated with the well-being of life.

The transition that occurs during the marriage period is experienced by every working couple and usually, the mother or woman is more impressed with this issue. An old study conducted by Galinsky, Bond, and Friedman (1996) states that married workers are more likely to experience marital conflict than single employees. This increases stress and affects well-being in the workplace. Subsequent studies were conducted by Panisoara and Serban (2012) and support the above statement that unhappy marriages will affect well-being in the workplace. Issues about married life can affect well-being in the workplace is not a new issue. While we usually evaluate relationships and careers are two different things but we will never run away from the fact that emotional experiences are subjective and interconnected with each other. The study of Hsu and Barrett (2020) states that marriage is interrelated with human wellbeing. Low autonomy in marriage, lack of self-acceptance, and lack of positive relationships with others will affect well-being in the workplace. While the study of Carr, Freedman, Cornman \& Schwarz (2014) discusses the quality of marriage and well-being in a relationship where the better the quality of the marriage, there is optimal well-being among wives. The results of the study prove that the quality of marriage and the satisfaction of life is the result of good well-being.

Finally, dedication to work can reduce involvement in the household. Ashiwini's (2018) study supports this statement by showing that there is a significant correlation between work-life balance and marital quality. This means that well-being can be measured if work and family can be well balanced. Well-being guarantees the long-term effects of marriage. 


\section{Method \\ Location}

This study chose Selangor as the study location. This location was chosen because Selangor is the state with the highest population density. Although, the Labor Force Survey Report 2015 revealed that the labor force participation policy was only 54 percent compared to 80.6 percent for men and the gender gap of 26.5 points. However, the female labor force participation rate in Selangor increased in 2016 and ranked 63.4 percent higher than 81.9 percent for men (gender gap of 18.5 points), this is not surprising because Selangor is the most developed state in Malaysia (Department of Statistics Malaysia, 2016).

The chosen area was Hulu Langat District, Selangor. According to the Department of Statistics Malaysia (2010), Hulu Langat District has seven Mukim. However, the researcher only selected three main Mukim to conduct this study, which were Kajang, Cheras, and Ampang.

These three areas were chosen because of their educational, transportation, medical, tourism, and residential facilities. Therefore, it provides easy access to researchers who focus on study respondents among working women.

\section{Participants}

To facilitate the researcher to collect data, this study has used the non-probability sampling method. There are two methods used in this study namely Snowball Sampling (Snowball) and Purposeful Sampling (Purposive).

Researchers use the purposive sampling method. The sampling method is intended to be used because the selected respondents must meet some of the criteria that have been set. Thus, other respondents who are in the study population that do not meet the set criteria will not be taken into account and will not have the opportunity to participate in this study. According to Ismail (2016), the advantage of this type of sample allows the use of moderate costs and is commonly used in other research such as socioeconomics. In addition, the sample studied also needs to meet certain objectives.

The second sampling method is snowball sampling. The concept of a snowball is to start small or a little later to get bigger or bigger as the snowball rolls from the top of the hill down and becomes bigger (Ismail, 2016). The use of snowball sampling allows data collection to be specific to specific groups and more effective methods to focus on specific groups (Howitt \& Cramer, 2011).

To complete this study, a sample of the study was taken from working women with the title of a mother who is still in the period of marriage, period of service and have children. The inclusive criteria set are still living with a spouse, having at least one child and being in service. Respondents' participation is voluntary and they can withdraw from the study at any time. The respondents of this study also consisted of private and government employees.

The sample size is the portion of the population taken through certain means and has certain characteristics, is clear and is considered capable of representing the entire number of samples (Anitawidanti, 2010; Ismail, 2016). Determining the sample required an accurate 
sampling so that this study has several samples that represent and can describe the maximum population conditions.

According to the Statistics of Women, Family and Society Malaysia (2016) the population distribution by gender in the district of Selangor in 2016 for the female population is 6,298.4 thousand people but the distribution for women working in the three districts selected by the study is not stated in any statistical distribution of the Department Statistics. Therefore, researchers have taken the number of samples taken in Kajang, Cheras, and Ampang based on the Selangor State Structure Plan 2035 and took the population distribution from employment statistics in the district of Hulu Langat, which was 224.6 thousand people in 2010.

To obtain the desired sample size accuracy the researcher has determined it through a minimum sample table by Krejic and Morgan (1970) which allows the determination of the level of confidence in the sample calculation. The researcher needed a total of 331 respondents as a study sample based on the determination of the sample size of Krejci and Morgan who have listed the sample size that corresponds to the size of the study population as Krejic \& Morgan (1970) table. However, 140 respondents were able to be collected for this research.

Psychological test instruments used in this research are Organizational Commitment Questionnaire (OCQ) by Porter and Smith (1970), Work-Family Conflict Questionnaire by Kelloway, Gottlieb, and Barham (1999), and Well Being at Work Scale by Paschoal and Tamayo (2008).

\section{Result}

\section{Workplace Well-Being in Marriage and Age of Working Women.}

Multiple linear regression analysis was performed to determine the significant expectations of well-being in the workplace throughout marriage and age among working women. Multiple regression analysis was used to look at the relationship between dependent variables and independent variables.

Multiple linear regression analysis was used to predict workplace well-being throughout marriage and age among working women. The analysis showed a significant relationship with the results of ANOVA $(F(137)=2.9995, p<0.053)$ with a value of $R$ square 0.42 . Respondents predict well-being in the workplace is equal to $90.240+3,710$ (Marriage Period) - 6.675 (Age), where the period of marriage is coded as $1=1-5$ years, $2=6-10$ years, $3=11-15,4=16-20$, $5=21$ years and above and age is coded as $1=20-29$ years, $2=30-39$ years, $3=40-49$ years, $4=50-59$ years and $5=60$ years and above. The increasing period of marriage $(3,710)$ and age $(6,675)$ can ensure well-being in the workplace. Therefore, the hypothesis is rejected because both of these variables are significant predictor factors on workplace well-being.

Researchers found that the results of the fourth hypothesis found that the age and duration of the marriage is a significant predictor factor on well-being in the workplace. This indicates that the older they get, the better the well-being of an individual in their workplace. In addition, the longer the marriage period, the better the well-being at work. 
There are several other predictor factors such as duration of service, number of children owned, level of education, service sector and field of employment. However, in this study, only predictive factors such as age and duration of marriage only show a significant relationship to well-being in the workplace. Prosperity in the workplace carries the meaning of the individual in carrying out their duties well with a full sense of responsibility, in balancing between negative affections and positive affections well as well as feeling the achievements they want are met and expected. Therefore, the age and duration of marriage have been identified as one of the predictive factors for working women to feel prosperous in the workplace.

Working women workers enjoy well-being as they get older as well-being in the workplace will increase progressively through the age factor. As we all know, the relationship between age and well-being is a complex relationship and future studies should be done comprehensively to assess whether different age factors have a relationship or not with wellbeing in the workplace.

Furthermore, population growth and some workloads cause the role of age to play an important factor in the relationship between job characteristics and job well-being (Finkelstein et al., 2015). Therefore, one of the ways to improve well-being in the workplace is for older workers or older workers to guide younger workers as an opportunity for them to gain experience and reduce stress. Stress in the workplace can have an impact on women compared to men because it is easier to form feelings of anxiety, fatigue, depression, irritability, and insomnia compared to men (Herbert, 2020). Therefore, through the mentormentee method, younger or new employees can learn how to improve their well-being than older employees.

As stated in the study of Kun and Gadanecz (2019), well-being in the workplace can be improved through good working relationships. This means that older people need to play a role in helping young people balance their feelings and emotions to maintain their mental and physical health manifestations. In addition, well-being in the workplace can also reduce fatigue and stress as well as increase productivity, motivation, and employee focus to achieve goals.

Windsor and Anstey (2010) describe age differences can be predictors of domains in wellbeing i.e. positive affective and negative affective i.e. older groups have relative emotional well-being compared to younger or middle-aged. They have better positive effects than negative effects when age is increasing. As we age, the more complex the way we process emotional information, the more positive it affects, and the less negative it is. In addition, it is possible that age factors for critical thinking also cause a decrease in psychophysiological responses to emotional stimuli to act with existing workloads (Lawto et al., 1992).

Age differences in the control of belief in well-being also lead to how they perceive negative effects at a young age (20 to 39 years). Controlling confidence and emotional reactivity leads to a reduction in internal stress and allows work-related negative effects to be minimized. This means that, with increasing age, the ability to control beliefs and emotional activity will improve and this will improve the well-being of individuals in the workplace. 
The stress of a marital relationship will manifest in the workplace and then more stressful when at home. The effects of domestic unrest will disrupt work productivity and the absence of workplace absences (Yu, 2018). Therefore, happy relationships produce happy couples and employees by producing high productivity and this will benefit the organization's profits. The marriage period has various phases that each couple goes through differently. Having a job and family life is not easy without going through experience to balance it. Various sacrifices need to be made to balance the two responsibilities at once (Panisoara \& Serban, 2012).

Marital satisfaction leads to long-term marital relationships and the quality of marriage is closely related to the duration of the marriage. The period of marriage here means good household stability. This means, the longer the marriage period, the better quality and stability (Katja et al., 2020). The meaning here is that marital satisfaction is a predictor factor to subjective well-being and human health. Improving the quality of a positive marriage provides well-being and further prolongs the marriage.

It explains that the longer the marriage period, the better the adaptation to it and in turn improve the well-being in the work order. Good quality can ensure the well-being and optimize the level of productivity in the workplace. Through long-term marital relationships, the absence of conflict and good quality, it will have an impact on human mental health. This situation will predict a successful working life.

Apart from that, a good marriage period also allows employees to achieve what they want in the workplace. Fulfillment (fulfillment) here is one of the domains in this study as one of the determining factors of well-being in the workplace apart from positive and negative affect. Opportunities to do their best in the workplace can be achieved if the employee is in good working performance condition. Moore (2018) says employees who give a strong commitment to the workplace environment are employees who have good household stability. The potential to do a good job is the result of a good marriage role.

\section{Summary}

Overall, this study can prove and contribute consistent research results in the world of research. Furthermore, the results of this study can also address the issues that exist and answer the problems of the study. Through the existence of such a study, it can provide awareness to the organization to create a good work environment for employees by becoming a company policy and policies that provide useful benefits to employees. In conclusion. work-family conflict, organizational commitment and well-being in the workplace are important issues that need to be taken into account and emphasized in industry and organization.

\section{References}

Abdullah, N. W., Shamsuddin, E., \& Noor, A. H. (2012). Perception on Career Barriers among Working Women. International Journal of Sustainable Development, 4, 93-100.

Ahmad, A., \& Ngah, N. (2011). Impact of Dispositional factors and Work-Family Conflict on Job Satisfaction among Single Mother Employees. American Journal of Applied Sciences, 8, $11,1107-1115$. 
Allen, N. J., \& Meyer, J. P. (1990). The Measurement and Antecedents of Affective, Continuance and Normative Commitment to The Organization. Journal of Occupational Psychology, 63, 1, 1-18.

Alex, B., Lucy, S., \& David, W. (2018). Are Schools Different? Wellbeing and Commitment among Staff in Schools and Elsewhere. IZA - Institute of Labor Economics.

Ahmad, A., \& Omar, Z. (2008). Gender Differences in Work-Family Conflict and Family-Friendly Employment Policy Practices. The International Journal of the Humanities, 6, 15-25.

Clark, A. E. (1996). Job Satisfaction and Gender: Why are Women so Happy at Work. Labour Economics, 4, 341-372.

Annisa dan Zulkarnain. (2013). Komitmen Terhadap Organisasi Ditinjau dari Kesejahteraan Psikologis Pekerja. Universitas Sumatera Utara INSAN, 15, 1, 54-62.

Anon. (2020). Budget: \#Malaysiakerja Initiative to Provide Jobs for Youth, Women. New Straits Times. October 11, 2019.

Al Jabri, B., \& Ghazzawi, I. (2019). Organizational Commitment: A Review of The Conceptual and Empirical Literature and A Research Agenda. International Leadership Journal, 11, 1, 78-119.

Akintayo, D. I. (2010). Work-Family Role Conflict and Organizational Commitment Among Industrial Workers in Nigeria. Journal of Psychology and Counseling. 2, 1, 1-8.

Puspitasari, A. (2011). Pengaruh Konflik Pekerjaan-Keluarga terhadap Komitmen Organisasi dengan Kepuasan Kerja. JEJAK, 5, 1, 73-81.

Karapinar, B. P., Camgoz, S. M., \& Ekmekci, T. O. (2019). Employee Wellbeing, Workaholism, Work-Family Conflict and Instrumental Spousal Support: A Moderated Mediation Model. Journal of Happiness Studies.

Bernard, H. R. (2002). Research methods in anthropology: Qualitative and Quantitative Approaches (3rd ed.). Walnut Creek, CA: Alta Mira Press.

Buhali, G. A., \& Margaretha, M. (2013). The Influence of Work Family Conflict on Organizational Commitment: Job Satisfaction as Intervening Variable. Management Journals, 13, 1, 15-33

Boult, M. (2019). Well Being in The Workplace. Why It Matters for Organizational Performance and How to Improve It. The Myers-Briggs Company and The Myers-Briggs Company Limited.

Byron, K. (2005). A Meta-Analytic Review of Work-Family Conflict and Its Antecedents. Journal of Vocational Behavior, 67, 2, 169-198.

Carlson, D. S., Kacmar, K. M., \& Williams, L. J. (2000). Construction and Initial Validation of a Multidimensional Measure of Work-Family Conflict. Journal of Vocational Behavior, 56, 2, 249-276.

Carr, D., Freedman, V. A., Cornman, J. C., Schwarz, N. (2014). Happy Marriage, Happy Life? Marital Quality and Subjective Well-being in Later Life. Journal of Marriage and Family.

Caught, K., Shadur, M. A., \& Rodwell, J. J. (2000). The Measurement Artifact in the Organizational Commitment Questionnaire. Psychological Reports, 87, 3, 777- 788.

Cao, J., Liu, C., Wu, G., Zhao, X., \& Jiang, Z. (2020). Work-Family Conflict and Job Outcomes for Construction Professionals: The Mediating Role of Affective Organizational Commitment.

International Journal of Environmental Research and Public Health, 17, 4, 1443.

Ping, C. S. (2014). Pengaruh Kesejahteraan di Tempat Kerja sebagai Pengantara Terhadap Hubungan antara Kepimpinan Transformasi Pengetua dan Budaya Dengan 
Penambahbaikan Organisasi Sekolah Utara Semenanjung Malaysia. Universiti Sains Malaysia.

Davis, T. S. (2013). Look on The Bright Side: Effects of Positive Reappraisal Training on Psychological Health. Society for Personality and Social Psychology, Emotion Preconference. New Orleans.

Demo \& Paschoal. (2016). Well-Being at Work Scale: Exploratory and Confirmatory Validation in the USA. Paidéia. 26, 63, 35-43.

Deci, E., \& Ryan, R. (2008). Hedonia, Eudaimonia, And Wellbeing: An Introduction. Journal of Happiness Studies, 9, 1, 1-11.

De Simone, S. (2014). The Affective Component of Workplace in Organizational Behavior Studies. American International Journal Contemporary Research, 4, 9, 38-43.

Drummond, S., O’Driscoll, M. P., Brough, P., Kalliath, T., Siu, O. L., Timms, C. (2017). The Relationship of Social Support with Well-Being Outcomes Via Work-Family Conflict: Moderating Effects of Gender, Dependents, And Nationality. Human Relations, 70, 5, 544-

Etikan I., Musa, S. A., and Alkassim, R. S. (2016). Comparison of Convenience Sampling and Purposive Sampling. American Journal of Theoretical and Applied Statistics, 5, 1, 1-4.

Evangelia Demerouti, Sabine Sonnentag, Eva J. Mojza, \& Arnold B. Bakker. (2012). Reciprocal Relations Between Recovery and Work Engagement: The Moderating Role of Job Stressors. Journal of Applied Psychology.

Faloye, D. O. (2014). Organizational Commitment and Turnover Intentions: Evidence from Nigerian paramilitary organization. International Journal of Business \& Economic Development, 2, 3, 23-34.

Fisher, C. D. (2014). Conceptualizing and Measuring Wellbeing at Work. Wellbeing, 1-25.

Ghasemi, A., \& Zahediasl, S. (2012). Normality Tests for Statistical Analysis: A Guide for NonStatisticians. International Journal of Endocrinology and Metabolism, 10(2), 486-489.

Greenhaus, J. H., \& Beutell, N. J. (1985). Sources of Conflict between Work and Family Roles. Academy of Management Review, 10, 1, 76 - 88.

Gutek, B. A., Searle, S., \& Klepa, L. (1991). Rational Versus Gender Role Explanations for WorkFamily Conflict. Journal of Applied Psychology, 76, 4, 560 - 568.

Higgins, C., Duxbury, L., \& Lee, C. (1994). Impact of Life-Cycle Stage and Gender on The Ability to Balance Work and Family Responsibilities. Family Relations, 43, 144 - 150.

Helen, R. W., Carolyn, B., \& Anthony, H. W. (2014). Work-Family Conflict and Well-Being in University Employees. University of South Australia.

Hur, E., Jeon, L., \& Buettner, C. K. (2016). Preschool Teachers' Child-Centered Beliefs: Direct and Indirect Associations with Work Climate and Job-Related Wellbeing. Child \& Youth Care Forum, 45, 451-465.

Jabatan Perangkaan Malaysia. (2018). Statistik Utama Tenaga Buruh, Malaysia, Suku Pertama, S1.

Jabatan Perangkaan Malaysia. (2017). Statistik Pemerkasaan Wanita dalam Domain Terpilih, Malaysia 2017.

Jabatan Perangkaan Malaysia. (2016). Laporan Penyiasatan Tenaga Buruh, Malaysia, 2015.

Jabatan Perangkaan Malaysia. (2016). Perangkaan Wanita, Keluarga dan Masyarakat Malaysia.

Jabatan Perangkaan Malaysia. (2010). Taburan Penduduk dan Ciri-Ciri Penduduk, 2010. 
Jenitta, J. N., Elangkumaran, P. (2013). An Impact of Work Family Conflict on Organizational Commitment: A Study of Staff Members at People's Bank in Trincomalee District. International Journal of Research in Commerce \& Management. 4, 11.

Juniarly, A., Purnamasari, A., Anggaraini, D., \& Andini, H. (2018). Emotional Intelligence, Subjective Wellbeing, and Work-Family Conflict Among University Lecturers. ANIMA Indonesian Psychological Journal, 33, 4.

Karambayya, R., \& Reilly, A. H. (1992). Dual Earner Couples: Attitudes and Actions in Restructuring Work for Family. Journal of Organizational Behavior, 13, 585 - 601.

Kopelman, R. E., Greenhaus, J. H., \& Connolly, T. F. (1983). A Model of Work, Family and Interrole Conflict: A Construct Validation Study. Organizational Behavior and Human Performance, 32, $198-215$.

Macewen, K. E., \& Barling, J. (1988). Inter-role Conflict, Family Support and Marital Adjustment of Employed Mothers: A Short Term, Longitudinal Study. Journal of Organizational Behavior, 9 (3), $241-250$.

Meyer, J. P., Allen, N. J. (1991). A Three-Component Conceptualization of Organizational Commitment. Human Resource Management Review, 1, 61-89.

Meyer, J. P., Stanley, D. J., Herscovitch, L., \& Topolnytsky, L. (2002). Affective, Continuance, and Normative Commitment to the Organization: A Meta-analysis of Antecedents, Correlates, and Consequences. Journal of Vocational Behavior, 61, 1, 20-52.

Meyer, J. P., \& Maltin, E. R. (2010). Employee Commitment and Well-Being: A Critical Review, Theoretical Framework and Research Agenda. Journal of Vocational Behavior, 77, 2, 323-337.

Michel, J. S., Mitchelson, J. K., Kotrba, L. M., LeBreton, J. M., \& Baltes, B. B. (2009). A Comparative Test of Work-Family Conflict Models and Critical Examination of WorkFamily Linkages. Journal of Vocational Behavior, 74, 2, 199-218.

Mowday, R. T., Steers, R. M., \& Porter, L. W. (1979). The Measurement of Organizational Commitment. Journal of Vocational Behavior, 14, 2, 224-247.

Ngah, N., Ahmad, A., Hamid, T. A. T. A., and Ismail, A. (2010). The Mediating Role of WorkFamily Conflict in the Relationship between Supervisor Support and Job Satisfaction. International Journal of Interdisciplinary Social Sciences, 4, 11, 187-197.

Musida, N., \& Sombuling, A. (2017). Pengaruh Konflik Kerja-Keluarga terhadap Kepuasan Hidup dalam kalangan Ibu Bapa. Jurnal Psikologi Malaysia, 31, 3, 19-30.

Noor, N. A. (2004). Work-Family Conflict, Work- And Family-Role Salience, And Women's Well-Being. Journal of Social Psychology, 144, $389-405$.

Oshagbemi T. (1997). Job Satisfaction and Dissatisfaction in Higher Education. Education \& Training. 39, 9, 354-359.

Pryce-Jones, J. (2010). Happiness at Work: Maximizing Your Psychological Capital for Success. NJ: Wiley Blackwell Publishing.

Porter, L. W., Steers, R. M., Mowday, R. T., \& Boulian, P. V. (1974). Organizational Commitment, Job Satisfaction and Turnover Among Psychiatric Technicians. Journal of Applied Psychology, 59, 5, 603-609.

Parasuraman, S., Greenhaus, J. H., \& Granrose, C. S. (1992). Role Stressors, Social Support, And Well-Being Among Two-Career Couples. Journal of Organizational Behavior, 13, $339-356$.

Parasuraman, S., Greenhaus, J. H., Rabinowitz, S., Bedeian, A. G., \& Mossholder, K. W. (1989). Work and Family Variables as Mediators of The Relationship Between Wives' 
Employment and Husbands' Well-Being. Academy of Management Journal, 32, 185201.

Parasuraman, S., Purohit, Y. S., Godshalk, V. M., \& Beutell, N. J. (1996). Work and Family Variables, Entrepreneurial Career Success, and Psychological Well-Being. Journal of Vocational Behavior, 48, 275-300.

Panisoara, G., \& Serban, M. (2012). Marital Status and Work-Life Balance. Social and Behavioral Sciences, 78, 21-25.

Rathi, N., \& Barath, M. (2013). Work-Family Conflict and Job and Family Satisfaction. Equality, Diversity and Inclusion: An International Journal, 32, 4, 438-454.

Ryu, E. (2011). Effects of skewness and kurtosis on normal-theory based maximum likelihood test statistic in multilevel structural equation modeling. Behavior Research Methods, $43,4$.

Aazami, S., Akmal, S., \& Shamsudin, K. (2014). Validation study of the Malay version of the Work Family Conflict Questionnaire. Malays J Med Sci, 21, 1, 50-57.

Schermerhorn, J. R. Jr., Hunt, J. G., \& Osborn, R. N. (1991). Making Organizational Behavior: Communication \& Conflict (4th Ed.). USA: John Wiley \& Sons, Inc.

Schaufeli, W. B., and Salanova, M. (2007). Work Engagement: An Emerging Psychological Concept and Its Implications for Organization, In Gilliland, S.W., Steiner, D.D. And Skarlicki, D.P. (Eds), Research in Social Issues in Management: Vol. 5. Managing Social and Ethical Issues in Organizations, Information Age Publishers, Greenwich, CT, pp. 135177.

Huang, S. H. Li, R. H., Fang, S. Y., \& Tang, F. C. (2019). Well-Being: Its Relationship with Workto-Family Conflict and Burnout among Males and Females. International Environment Res. Public Health 2019, 16.

Spector, P. E. (1985). Measurement of Human Service Staff Satisfaction: Development of The Job Satisfaction Survey. American Journal of Community Psychology, 13, 693-713.

Singh, A., \& Gupta, B. (2015). Job Involvement, Organizational Commitment, Professional Commitment, And Team Commitment. Benchmarking: An International Journal, 22, 6, 1192.

Firdaus, S. N. (2018). Komitmen Organisasi Sebagai Mediator Dalam Hubungan Antara Kecerdasan Emosi Dan Kepuasan Kerja Dengan Prestasi Kerja. Tesis Sarjana. Universiti Kebangsaan Malaysia.

Firdaus, S. N. (2019). Pengaruh Personaliti Perfeksionisme dan Konflik Kerja Keluarga terhadap Kepuasan Perkahwinan: Daya Tindak Diadik Sebagai Pemboleh Ubah Pengantara. Universiti Kebangsaan Malaysia.

Tuna, M., Ghazzawi, I., Tuna, A., \& Catir, O. (2016). Perceived External Prestige and Organizational Deviance: The Case of Turkey's Hospitality Industry. Forthcoming in the International Journal of Contemporary Hospitality Management (IJCHM), 28, 2, 366396.

Vijaya, T. G., \& Hemamalini, R. (2011) Organizational Role Stress and Work Life balance among IT Professionals. International Journal of Business Economics and Management Research, 2, 8, 76-85.

Webber, A. (2019). Staff Wellbeing Improves with Age, Study Finds. Occupational Health \& Wellbeing.

Williams, G. M., \& Smith, A. P. (2012). A Holistic Approach to Stress and Well-Being. Part 6: The Wellbeing Process Questionnaire (WPQ Short Form). Occupational Health (At Work), 9, 1, 29-31. 
Williams, G., \& Smith, A. P. (2013). Measuring Wellbeing in The Workplace: Single Item Scales of Depression and Anxiety. In Contemporary Ergonomics and Human Factors 2013. Martin Anderson (Ed). CRC Press: Taylor \& Francis. London.

Zacher, H. (2015). Successful Aging at Work. Work Aging Retirement 1, 4-25.

Zhou, S., Da, S., Guo, H., \& Zhang, X. (2018). Work-Family Conflict and Mental Health among Female Employees: A Sequential Mediation Model via Negative Affect and Perceived Stress. Frontiers in Psychology, 9. 